\title{
INDICATIONS FOR SURGICAL INTERVENTION IN RHEUMATOID ARTHRITIS OF THE WRIST AND HAND
}

\author{
J. C. F. CREGAN \\ Manchester
}

The problems of prolonged disability and pain in the wrist and hand resulting from rheumatoid arthritis are well known, and the management of this generalized disease is primarily a medical problem. Various open operations on these parts have, however, been devised to relieve pain and improve function; it is the purpose of this paper to re-examine the value of some of these and to clarify the indications for their use.

\section{Material}

290 polyarthritic patients have been examined over a 6-year period, 265 of them referred to out-patient departments and 25 seen as in-patients, in the South Manchester area hospitals and at the Devonshire Royal Hospital, Buxton. In all cases, the hands and the wrists were affected, but in only 120 was this the primary reason for hospital attendance.

The patients do not represent a complete cross-section of the total rheumatoid population as they had all been referred to out-patient departments or admitted as inpatients, and the milder forms of arthritis were therefore not included. 71 of these patients were operated on, and the type of operation and sex distribution are shown in Table I. All patients were questioned about hand disabilities whether they were complaining of them or not.

The operations were all performed by the same surgeon, who also assessed the operative results. The assessment was based on the patients' statements, the physical signs, and when possible by comparisons with similar controls or with the same condition in the other hand.

\section{Reasons for Advising Operation}

(1) Persistent local pain not permanently improved by conservative treatment for 6 months or more; three main types of pain were found:

(a) Metacarpophalangeal joint pain due to subluxation.

(b) Pain over the inferior radio-ulnar joint and ulnar side of the wrist.

(c) Pain over the front of the wrist and lower forearm due to flexor tenovaginitis.
TABLE I

SURGICAL PROCEDURES USED IN 71 CASES, BY SEX.

\begin{tabular}{|c|c|c|c|}
\hline \multirow{2}{*}{ Surgical Procedure } & \multirow{2}{*}{ No. of Cases } & \multicolumn{2}{|c|}{$\operatorname{Sex}$} \\
\hline & & Male & Female \\
\hline $\begin{array}{l}\text { Radiocarpal fusion and ex- } \\
\text { cision of lower end ulna }\end{array}$ & 5 & 1 & 4 \\
\hline Excision of lower end of ulna & 14 & 5 & 9 \\
\hline $\begin{array}{l}\text { Excision of flexor sheath and } \\
\text { division of anterior carpal } \\
\text { ligament } \\
\end{array}$ & 7 & 0 & 7 \\
\hline $\begin{array}{cccc}\begin{array}{l}\text { Metacarpophalangeal } \\
\text { Methro- } \\
\text { desis }\end{array} & \ldots & \ldots & \ldots \\
\end{array}$ & 4 & 0 & 4 \\
\hline Shortening of first metacarpal & 8 & 1 & 7 \\
\hline Extensor tendon repair & 14 & 2 & 12 \\
\hline \begin{tabular}{cccr}
$\begin{array}{c}\text { Persistent } \\
\text { effusion }\end{array}$ & extensor & \multicolumn{2}{c}{ sheath } \\
& $\ldots$ & $\ldots$ & $\ldots$ \\
\end{tabular} & 2 & 0 & 2 \\
\hline Excision of metacarpal heads & 12 & 5 & 7 \\
\hline $\begin{array}{l}\text { Arthroplasty of proximal inter- } \\
\text { phalangeal joints } \quad \ldots\end{array}$ & 5 & 1 & 4 \\
\hline Total ... & 71 & 15 & 56 \\
\hline
\end{tabular}

(2) A major permanent deficiency of grasp for individual needs; four main types of grasp deficiency were found:

(a) Defective function in the thumb.

(b) Incorrigible deformity of the wrist.

(c) Defective finger flexion.

(d) Tendon ruptures.

In many patients two or more of these factors co-existed, but usually one was dominant. The general state of the disease was considered, and if the patient was not in the ascending phase of an exacerbation, as judged by the history clinical examination and the erythrocyte sedimentation rate, a local increase of heat and swelling at the operation site was not regarded as a contra-indication to surgery; no generalized "flare-ups" have been seen as an obvious result of operation. Psychological factors 
were not troublesome, as those patients whom surgery might have helped, but who were temperamentally resistant to rehabilitation, refused operation.

\section{Operative Methods Employed}

(1) Wrist.-In this group 26 operations were performed, all with good results, ${ }^{*}$ and twelve patients were not treated by surgery (Table II).

TABLE II

RESULTS OF 26 OPERATIONS ON WRISTS

\begin{tabular}{c|c|c|c}
\hline Surgical Procedure & Operated & $\begin{array}{c}\text { Not } \\
\text { Operated }\end{array}$ & $\begin{array}{c}\text { Results in } \\
\text { Operated } \\
\text { Cases }\end{array}$ \\
\hline $\begin{array}{l}\text { Radiocarpal fusion and } \\
\text { excision lower end of } \\
\text { ulna . } \ldots \quad \cdots \quad \cdots\end{array}$ & 5 & 0 & All good* \\
\hline $\begin{array}{l}\text { Excision lower end of } \\
\text { ulna alone } \ldots\end{array}$ & 14 & 8 & All good \\
\hline $\begin{array}{l}\text { Excision of flexor sheath } \\
\text { and division of an- } \\
\text { terior carpal ligament }\end{array}$ & 7 & 4 & All good \\
\hline
\end{tabular}

(a) Radio-curpal Fusion and Excision of Lower End of Ulna.-All five patients in this category had fixed flexion deformities of the wrist with bony or tight fibrous ankylosis, and these were corrected by wedge resection and arthrodesis of the radio-carpal joint using the lower end of the ulna as inlay graft material. In all cases the grasp was improved satisfactorily, but rotation improved no more than $20^{\circ}$ in any case. A reasonable degree of passive finger range was present beforehand; the absence of this was considered to be a bar to operation, and several patients were not operated on for this reason.

52 patients showed clinical instability of the wrist joint with some pain, but the disability was considered too slight to warrant arthrodesis.

(b) Excision of Lower End of Ulna Alone.-This was carried out on fourteen wrists, in all of which there was a painful subluxation at the inferior radioulnar joint; the results were variable (Table III).

TABLE III

RESULTS OF EXCISION OF ULNA

\begin{tabular}{|c|c|c|c|}
\hline \multicolumn{2}{|c|}{$\begin{array}{c}\text { Average } \\
\text { Rotatory Range }\end{array}$} & $\begin{array}{c}\text { Pre- } \\
\text { operatively }\end{array}$ & $\begin{array}{l}1 \text { year Post- } \\
\text { operatively }\end{array}$ \\
\hline \multirow{2}{*}{$\begin{array}{c}\text { Excision } \\
\text { of } \\
\text { Ulna }\end{array}$} & $1 \mathrm{in.}$ & $30^{\circ}$ & $50^{\circ}$ \\
\hline & $2 \frac{1}{2}$ in & $30^{\circ}$ & $90^{\circ}$ \\
\hline
\end{tabular}

* "Good" implies (1) Fusion of bone as a result of operation on the carpus, (2) no loss of grip after operation, (3) subjective impression that the hand was more useful and less painful after operation.
All patients gained good relief of pain, and this was appreciated even if the gain in rotation was slighte. as in the six cases in which only 1 in. of the ulnain. was removed. In the other eight cases in whick $2 \frac{1}{2}$ in. of the ulna was removed, there was a greaథ increase in the average rotation and no real difference in the small amount of post-operative ulnar deviatiof which was apparently symptomless.

(c) Excision of Flexor Sheath above the Writis and Division of Anterior Carpal Ligament.-This wast carried out in seven patients (one hand each) to relieve pain which had lasted for 8 months or morew In five of these patients (of whom two had alreads been treated by local hydrocortisone injection $\tilde{\Sigma}$ there was already a general rheumatoid infection $\dot{0}$ but in the other two there were no systemic symptoms, and the subacute flexor tenosynovitis was the first indication of the disease, which declared itsel 18 and 6 months later respectively. In these two cases the pain was particularly intense, preventin sleep and resisting drugs or splinting. All thఖ tendon sheaths, when exposed at operation, wers found to be swollen, opaque, and yellow from their proximal limits distally to the distal margin of the carpal tunnel. In one patient with generalized rheumatoid infection the common palmar sheath io the hand was also slightly opaque. The thickenee sheaths were excised, and the anterior carpa ligament completely divided. The pain was relieves immediately and has not recurred.

In four similar untreated patients, observed ove $\overrightarrow{\overrightarrow{0}}$ periods of 2 to 3 years, the swelling has remained, but the pain though still present can be relieved bu analgesic drugs and has become less distressing

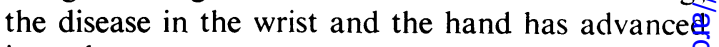
in each case.

(2) Thumb.-Inability to make use of the thumb was found to be one of the worst single disabling factors; two main types of case were seen and twelve operations were performed (Table IV).

TABLE IV

RESULTS IN TWELVE OPERATIONS ON THUMBS

\begin{tabular}{|c|c|c|c|}
\hline Surgical Procedure & & No. of Cases & Results \\
\hline $\begin{array}{l}\text { Metacarpophalangeal } \\
\text { arthrodesis }\end{array}$ & . & 4 & All good \\
\hline $\begin{array}{l}\text { Metacarpal shortening } \\
\text { for ankylosis }\end{array}$ & . & $\begin{array}{l}8 \\
\text { (6 Still's } \\
\text { Disease) }\end{array}$ & $\begin{array}{c}3 \text { Bad } \\
5 \text { Good } \\
\text { (Interposition } \\
\text { material used) }\end{array}$ \\
\hline
\end{tabular}

(a) Radial Subluxation and Instability at the Meti苗 carpophalangeal Joint with Loss of Thumb: Inde $\frac{\text { P }}{\mathbb{W}}$ Opposition.-This was treated by arthrodesis of the

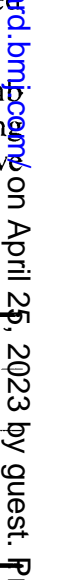


metacarpophalangeal joint in four hands with good restoration of the thumb : index opposition. Two patients have since asked for similar operations on the other thumb. The interphalangeal joint was also subluxed in two cases but arthrodesis was not carried out.

(b) Fixed Deformity of the Whole Thumb in Bad Position.-This was treated in eight patients (one thumb each) of which five were cases of inactive Still's disease. In all these, complete bony fusion had occurred at the wrist in neutral or slight flexion, and at the two distal thumb joints in full extension, the thumb being adducted in five cases and neutral in three. The finger range was limited to about $20^{\circ}$ at the metacarpophalangeal joint. The thumb could not be opposed to the stiff index and there was therefore virtually no active grasp in the hand at all.

The operation consisted of resection of the proximal third of the first metacarpal. In the first three patients the results were bad, the shaft reconstituting itself with complete bony re-ankylosis within a year. In the other five patients, absorbable gauze was introduced between the cut bony surfaces, after they had been smeared with bone wax; healing was good and though the initial post-operative range of movement diminished by about 20 per cent. in the first 6 months a satisfactory active pincer effect has remained unchanged in all five for periods ranging from $3 \frac{1}{2}$ years to 12 months.

(3) Tendon Lesions.-Twenty hands were affected and fourteen operations were performed (Table V).

TABLE V

RESULTS IN FOURTEEN OPERATIONS ON TENDONS

\begin{tabular}{c|c|c|c}
\hline $\begin{array}{c}\text { Tendon } \\
\text { Affected }\end{array}$ & Operated & $\begin{array}{c}\text { Not } \\
\text { Operated }\end{array}$ & $\begin{array}{c}\text { Results in } \\
\text { Operated Cases }\end{array}$ \\
\hline $\begin{array}{c}\text { Extensor pollicis } \\
\text { longus } \ldots\end{array}$ & 7 & 4 & $\begin{array}{c}\text { Good if repaired } \\
\text { by tendon transfer }\end{array}$ \\
\hline $\begin{array}{c}\text { Extensor digitorum } \\
\text { longus } \ldots\end{array}$ & $\ldots$ & 2 & Bad \\
\hline $\begin{array}{c}\text { Flexor pollicis } \\
\text { longus } \ldots\end{array}$ & 1 & 0 & Good \\
\hline
\end{tabular}

(a) Extensor Tendon Ruptures.-These were seen in nineteen patients (one hand each) with established rheumatoid disease with deformity which had usually come on after some weeks or months. The episodes of pain marking the rupture had been noted by all patients, but had caused relatively little alarm at the time. Thirteen of these tendons were repaired by direct suture or tendon transfer, but the deformity recurred early in eight cases despite 3 weeks' postoperative splintage from the forearm to the proximal phalanx.
The residual deformity in both treated and untreated cases was more troublesome after ruptures of extensor pollicis longus than after rupture of extensor digitorum longus, and the results of tendon transfer were all far better than after direct suture. In one patient, in whom a good technical result was obtained from early suture of extensor digitorum longus, some loss of terminal finger flexion in the ring and little fingers actually decreased the power of grasp.

(b) Flexor Tendon Ruptures.-One example of flexor pollicis longus rupture in the hand was repaired with a good result, though only 50 per cent. of interphalangeal flexion was regained.

(c) Flexor Tendon Nodules in the Palm.-These were seen in 41 hands none of which were operated upon. In the 25 cases which could be traced and re-examined, the symptoms had ceased to be disabling within a year or so.

(d) Persistent Extensor Sheath Effusions.-These were seen in seventeen hands, but were removed in only two, largely because of their size. These two patients were pleased with the cosmetic result, but in one small but significant loss of finger flexion occurred. This operation has not been repeated in any one patient.

(4) Digits.-Seventeen operations were carried out (Table VI).

TABle VI

RESULTS IN SEVENTEEN OPERATIONS ON DIGITS.

\begin{tabular}{|c|c|c|}
\hline Surgical Procedure & No. of Cases & Results \\
\hline Excision of metacarpal head ... & 12 & Good \\
\hline Interphalangeal arthroplasty & 5 & Bad \\
\hline
\end{tabular}

(a) Excision of Second and Fifth Metacarpal Heads and Necks.-This was carried out to relieve pain in twelve hands, all of which showed good results. Four patients requested the same operation on the other hand. Nine patients demonstrated that their grasp was better, although the postoperative metacarpophalangeal flexion range showed only an average increase of 20 per cent. at the most. After this operation the hand is shorter, and the oblique palmar furrow potentially deeper, so that the ulnar three fingers can more efficiently oppose the thenar eminence; this appears to be the reason for the improvement in grasp.

(b) Arthroplasty of Fingers.-Excision of the proximal interphalangeal joint was carried out in five patients (the middle finger in three and the index 
finger in two). In each finger both interphalangeal joints were ankylosed in the straight or hyperextended position. On the operating table it was noticed that in every case flexion at the pseudarthrosis of more than $20^{\circ}$ or so produced a pale cyanosis of the finger tip; indeed, one finger had to be amputated for dry gangrene a week after operation, though it was on light traction, and not flexed. After 6 months the results in all the remaining cases were poor, the distal segment subluxing backward, probably through contracture of the extensor mechanism over the back of the finger.

\section{Discussion}

Considering this series as a whole, it is clear that open operation has a relatively small part to play in the treatment of the rheumatoid hand and wrist. The pain usually responds to conservative treatment, and many of the inevitable deformities are compatible with good painless function. In the whole series of 290 cases, no voluntary complaints were made over painless metacarpophalangeal subluxation, ulnar deviation of the fingers and hand, dislocation of the extensor tendons, loss of finger extension, or instability of the wrist, and it seems that the presence of these deformities is not, in itself, an indication for operation. When, however, there is a fixed wrist deformity with mobile fingers or a thumb which is either unstable, or because of ankylosis, not opposable, operation is beneficial. In the latter event simple metacarpal shortening should be supplemented by interposed material.

With regard to pain as an indication for surgery: where the level of local pain remains high despite treatment, and sleep is persistently disturbed for many months, pain can and should be relieved by one of the above methods. The results obtained by excision of the flexor sheath and division of the carpal ligament were the most impressive, though it must be uncommon to see the disease presenting initially in this way. In dealing with extensor tendon ruptures the best results were undoubtedly obtained with recent ruptures of the extensor pollicis longus, a wrist extensor being used as a motor; the longer the period that elapsed before repair, the worse the result, and in ruptures of the extensors to the middle, ring, and little fingers which were some weeks old, repair has been unsatisfactory.

No direct correction of intrinsic contracture was carried out in this series, as the interphalangeal joints were already stiff in those cases in which it might have helped. The problem of converting the fixed hyperextension of the fingers into useful flexion is not solved. The answer may lie in earlier division of the lumbrical and interosseous insertions, or in interosseous stripping before joint stiffness is established, and this is being investigated. Nor? were any operations performed on the 41 patient? with flexor tendon nodules in the palm, as theiro symptoms had ceased to be troublesome within year or so in the 25 which could be traced for re-examination.

\section{Summary}

A series of 290 patients with rheumatoid arthritis has been reviewed over a period of 6 years, in order to discover how function in the wrist and hand $\overrightarrow{p o}$ may be improved by surgery. A total of 71 opera tions was performed.

The indications for surgery are assessed in the light of the results of these operations. It is con- cluded that these indications are infrequent. They are clear, however, in our present state of know ledge, in certain well-defined cases of persistent pain, weakness of grasp, stiffness, and deformity.

I wish to thank Prof. J. H. Kellgren, Dr. H. Stuare Barber and Dr. R. Harris for permission to report cases under their care, and Prof. Kellgren for advice anch 'criticism.

\section{BIBLIOGRAPHY}

Addison, N. V. (1954). Brit. J. Surg., 41, 511.

Ansell, B. M., and Bywaters, E. G. L. (1953). Ann. rheum. Dis, 12, 283 .

Brewerton, D. A. (1957). Ibid., 16, 183.

Bunnell, S. (1953). J. Bone Jt Surg., 35A, 88

(1955). Ibid., 37A, 759.

Harris, C., and Riordan, D. C. (1954). Ibid., 36A, 10

Harris, R. (1951). Ann. rheum. Dis., 10, 298.

Jacobs, J. H., Hess, E. V., and Beswick, I. P. (1957), J. Bone JP Surg., 39B, 288.

Kellgren, J. H., and Ball, J. (1950). Ann. rheum. Dis., 9, 48.

Law, W. A. (1952). J. Bone Jt Surg., 34B, 215.

Steindler, A. (1951). Ibid., 33A, 849.

Vainio, K., and Oka, M. (1953). Ann. rheum. Dis., 12, 122.

Indications de l'intervention chirurgicale dans l'arthrite $\mathrm{N}$ rhumatismale du poignet et de la main

\section{RÉSUMÉ}

On étudia pendant 6 ans une série de 290 malades $\sigma$ atteints d'arthrite rhumatismale afin de trouver commenk peut-on améliorer chirurgicalement la fonction dîE poignet et de la main. On procéda à 71 opérations end tout.

On détermine les indications chirurgicales à la lumière des résultats de ces opérations. On conclut que ces indications sont rares. Elles sont nettes, cependant, l'état actuel de nos connaissances, dans certains cas bien尺्? définis de douleur persistante, faiblesse de la prise $\mathbb{\nabla}$ raideur et déformation. 
Indicaciones de la intervención quirárgica en la artritis reumatoide de la muñeca y de la mano

\section{Sumario}

Se estudió durante un período de 6 años una serie de 290 enfermos con artritis reumatoide con el fin de descubrir como se puede mejorar quirúrgicamente la función de la muñeca y de la mano. Se efectuaron 71 operaciones en total.

Se determinan las indicaciones quirúrgicas a la luz de los resultados de estas operaciones. Se concluye que estas indicaciones son raras. En el estado actual de nuestros conociminetos hay, sin embargo, indicaciones claras en casos bien definidos de dolor persistente, débil asimento, rigidez y deformación. 